\title{
Apokaliptiek en eskatologie: Die verband en onderskeid volgens Walter Schmithals
}

\author{
Piet B Boshoff (Vereeniging) ${ }^{1}$ \\ Navorsingsassosiaat: Departement Nuwe-Testamentiese Wetenskap \\ Universiteit van Pretoria
}

\begin{abstract}
The relation between apocalyptics and eschatology according to Walter Schmithals

The article unfolds the development from the apocalyptic view of life to the eschatological one, as seen by Walter Schmithals. The historical Jesus was part of the apocalyptic movement. The message of the early church acknowledges the expectation of the apocalyptic movement but recognizes a specific fulfilment thereof.
\end{abstract}

\section{INLEIDING}

Vir 'n buitestander sou dit kon voorkom dat hier maar weer 'n droë teologiese tema aangeraak word. So 'n siening sal lesers egter net tot hulle eie nadeel weerhou om nader kennis te maak met gedagtes wat in werklikheid uit die hart van die Christelike teologie kom. Een invalshoek tot die tema bied die karakterisering wat lank gelede gemaak is van Lutherane en Gereformeerdes:

De Lutheraan voelt zich zalig in het heden; hij heeft het heerlijk bewustzijn gerechtvaardigd te zijn, en drukt dat uit in zijn lied, waarvoor hij het charisma bezit. De Gereformeerde streeft meer vooruit naar de volle heilligmaking, die hij maar al te diep gevoelt nog niet te bezitten. De geloovige Lutherse zegt: mijn Jezus dien ik heb, is mij meer waard dan duizend hemelen; ik vraag niet

\footnotetext{
1 Dr Piet Boshoff is as navorsingsassosiaat betrokke by prof dr Andries $\mathrm{G}$ van Aarde se navorsingsprojek "Bybelse teologie en hermeneutiek", Departement Nuwe-Testamentiese Wetenskap, Fakulteit Teologie, Universiteit van Pretoria.
} 


\section{Apokaliptiek en eskatologie}

naar wereld of hemel, slechts Jezus en zijn licht wil ik zien! De gereformeerde kan niet zoo jubelen; hij kan het niet vergeten dat die Jezus hem nog slechts de gids naar dien hemel is, en dat hij nog altoos hoopt op dien hemel, en nog verre is van zijn bezit.

(Gunning 1890:33)

Sou dit geoorloof wees om die kritiese vermoë van die leser uit te daag om self daarop te antwoord of hierdie indeling van kerkgroepe rofweg sou saamval met die tipering van eskatologie en apokaliptiek wat hierop volg? Is die Gereformeerde standpunt nie te apokalipties nie?

\section{JESUS}

Schmithals $(1973: 118 ; 1975: 67 ; 1994: 16-18)$ meen dat daar niks meer as losstaande opmerkings te mak is oor die aard van Jesus se lewe nie. Hoewel dit afsonderlike opmerkings is, kan hulle saam onder die beeld van Jesus as apokaliptikus groepeer word:

- Johannes die Doper was die geestelike vader van Jesus (vgl Geyser 1951:139141). Jesus is deur Johannes gedoop en het van sy boodskap uitgegaan en hierdie boodskap was apokalipties afgestem. Johannes het tot bekering geroep, want die toekomende Goddelike toorn is op hande. Dié wat hulle bekeer en wie se berou deur sy doop verseël is, is van die komende wêreldoordeel gevrywaar en verseker van die komende heil in die aanbrekende heerskappy van God (Schmithals $1973: 115 ; 1975: 67 ; 1979: 75-76 ; 1994: 16)$. Ook Jesus is voor die oordeel verseël deur die doop en het Hom aangesluit by die heilige volk van God.

- Die belydenis van Jesus se opwekking uit die dood is die gevolg van die werk wat Hy gedoen het. En hierdie belydenis van die opstanding uit die dood is ook 'n sentrale uitspraak van die apokaliptiek. Die oudste paasgeloof dui die opstanding van Jesus ook aan as die begin van die algemene opstanding uit die dood. Jesus is die "eersteling van die ontslapenes" (1 Kor 15:20; Schmithals 1975:67; 1994:1617). Die uitdrukking "eersteling van die ontslapenes" bring die verwagting onder woorde dat die eindgebeure nou op hande is. Hierdie verwagting was 'n wesen- 
like deel van die hoop wat die dissipels, wat Jesus in sy aardse lewe gevolg het, gekoester het (Schmithals 1973:115; 1994:17).

- Die voor-Pauliniese formule Romeine 1:3b-4a: "Wat stam uit die saad van Dawid as historiese mens; wat ingestel is as die magtige Seun van God deur die Heilige Gees, uit die opstanding van die dooies" sê van Jesus dat Hy 'n nasaat van Dawid is soos wat van die Messias verwag is, maar nogtans net 'n mens. Dat Hy die "Seun van God wat met mag beklee is" kan wees, is aan die werk van die Heilige Gees te danke, "uit die opstanding van die dooies". Na die apokaliptiese voorstelling is Hy die eerste opgewekte en die Christusbelydenis berus op die wending wat daarmee ingetree het (Schmithals 1994:17).

- Die kruisiging van Jesus deur die Romeine, wat onteenseglik die dood van 'n politieke misdadiger was, gee altyd daartoe aanleiding dat Jesus by een of ander groep politieke oproermakers ingedeel word. Schmithals (1975:67-68; 1994:17) kan sulke indelings nie aanvaar nie, omdat dit deur die vroeg-Christelike oorlewering en die houding van die oudste gemeentes weerspreek word. Tog het Jesus werklik die dood van 'n politieke teenstander van die staat gesterf. En al sou so 'n dood op 'n misverstand berus het, moes dit wat Hy gedoen het en die rol wat Hy gespeel het, op een of ander manier daartoe aanleiding gegee het. Schmithals soek hierdie aanleiding in die apokaliptiese verwagting wat Jesus gehad het. Hy het die einde van alle aardse heerskappye voorsien en aangekondig, en dit het die agterdog van die Romeinse owerheid gewek. Hulle het in hulle magsposisie bedreig gevoel. Die Romeine het nie onderskei tussen die apokaliptiese verwagting van die koms van die ryk van God en die revolusionêre Selotiese hoop op die Seun van Dawid nie.

- $\quad$ Schmithals $(1975: 68 ; 1994: 18)$ herlei die oorleweringskompleks in die Nuwe Testament waarin die Gees 'n belangrike rol speel, terug na 'n apokaliptiese oorsprong. Die gawes van die Gees, wat die Gees van die eindtyd is, wys die gemeente uit as die eskatologiese heilsgemeente (Schmithals 1974:103). Ook in die Jesus-oorlewering word teen verset teen die Gees van die eindtyd gewaarsku (Schmithals 1979:223-224; 1980:143): "Elkeen wat teen die Seun van die mens iets sê, kan vergewe word; maar hy wat teen die Heilige Gees laster, kan nie vergewe word nie" (Luk 12:10). 
Schmithals $(1973: 115 ; 1975: 68 ; 1994: 18)$ kom tot die konklusie dat die historiese Jesus wat die begin van sy optrede en sy uiteinde betref, deur twee fundamentele apokaliptiese motiewe - die eskatologiese boetedoop en die paasbelydenis - so nou as moontlik omsluit word. Hierby kan nog die kruisiging as politieke misdadiger deur die Romeine en die verkondiging van die Gees van die eindtyd gevoeg word om Jesus se optrede oortuigend in die raamwerk van die apokaliptiek te plaas.

Wat die onapokaliptiese gedeeltes van die Jesus-oorlewering betref, lug Schmithals $(1975: 84$, vgl 1985:402; 1994:19) twee moontlike verklarings. Sou die etiese vermanings ontstaan het met die uitbly van die verwagte wêreldeinde toe die kringe wat Jesus se apokaliptiese boodskap oorgeneem het, met die voortduur van die wêreld moes reken? Of het twee groepe, elkeen met 'n eie tradisie, saamgesmelt, die een draer van die apokaliptiese stof en die ander sterk eties georiënteerd?

\section{GESKIEDENIS VAN DIE OER-CHRISTELIKE ESKATOLO- GIE}

Schmithals (1979:379-380; 1994:23-24; vgl Bultmann 1980:39) maak onderskeid tussen die opstandingsbelydenis en die Messiasbelydenis, dit wil sê dat Jesus die Seun van God is. Dat Jesus uit die dood opgestaan het, is nog nie die volledige belydenis van die kerk nie; eers die belydenis dat Jesus Seun van God is, is die kerklike belydenis. Met die opstandingsbelydenis word Pase verduidelik as die aanbreek van die eindtyd in apokaliptiese sin (Schmithals 1979:725). Jesus is die eersteling van almal wat uit die dood gaan opstaan. Die salige toestand het aangebreek. Daarom wil Petrus die eindtydhutte bou as die eskatologiese figure van Moses en Elia verskyn: "Toe se Petrus vir Jesus: 'Rabbi, dit is goed dat ons hier is. Laat ons drie hutte bou: een vir U, een vir Moses en een vir Elia"” (Mark 9:5). Maar Petrus het met hierdie woorde nog net half-half verstaan. "Hy het nie geweet wat hy sê nie, so verskrik was hy" (Mark 9:6). Die kerklike belydenis sê nie bloot dat Jesus die eersteling van die opgestanes is nie; nie bloot "Hy leef" nie.

Die apokaliptiese verduideliking dat Jesus se opstanding die begin van die algemene eindtyd aandui, kon nie lank voortbestaan nie, omdat die eindtyd nie sigbaar aangebreek het nie. Die dooies het nie opgestaan nie. 'n Ander, nuwe interpretasie van die Paasgebeure sou moes kom om aan die kerk voortgang te gee. Hierdie nuwe 
interpretasie verneem Petrus van die hemelse stem: "Dit is my geliefde Seun. Luister na Hom" (Mark 9:7). Jesus se opstanding beteken sy proklamasie en intronisasie as Messias. Die regte erkenning van die Paasgebeure lui: " $U$ is die Christus." In plaas van die "Hy leef" verkondig die kerk "Hy regeer." Die uur van hierdie belydenis is die geboorteuur van die kerk en die begin van die Christelike teologievorming (Schmithals 1979:735-736). Simon Petrus het hierin 'n beduidende rol gespeel. Hy was aanvanklik 'n dissipel van Jesus; daarna die eerste getuie van die Paasgebeure; en daarna deur sy Messiasbelydenis die "rots" van die kerk (Schmithals 1979:738).

Die spanning wat in die geskiedenis van die vroeë kerk ondervind sou wees tussen Paulus en die tradisie van die historiese Jesus in die Sinoptiese Evangelies, tussen die Hellenistiese Christendom en die Palestynse tradisie, kan Schmithals herdefinieer in die sin dat Paulus nie alleen was in sy ignorering van die tradisie van die historiese Jesus nie. Paulus het hom aangesluit by die tradisie van die Hellenistiese Joodse Christendom waarin Jesus as die Seun van God verkondig is en reeds deur Petrus so geleer is (Schmithals 1988:51).

Volgens Schmithals (1972:23; 1975:71; 1994:20-21) begrond die Paasgebeure nie net die diskontinuïteit tussen die kerklike tradisie en die historiese Jesus-tradisie nie, tegelyk word ook die kontinuïteit tussen hierdie twee tradisies veronderstel. Die Paasboodskap knoop vas aan die verwagting wat Jesus verkondig het. Jesus het verwag dat die koninkryk van God spoedig sou kom. Die kerk gaan verder en sê dat die ryk van God aangebreek het. Die messias wat verwag is, is Jesus. Beide die diskontinuïteit en die kontinuïteit tussen die Christus-kerugma en die historiese Jesus-tradisie word begrond deur die skema van verwagting en vervulling. Die vervulling oortref die verwagting, maar staan tegelykertyd ook daarmee in verband.

Uit die raamwerk van sy eie siening oor die verloop van sake lewer Schmithals (1973:129; 1975:72; 1994:20) kommentaar op die uitspraak van Käsemann dat die apokaliptiek die moeder van die Christelike teologie is. Schmithals gee toe dat dit houdbaar is, solank die historiese verhouding tussen Christendom en apokaliptiek ter sprake is. Maar wat die saaklike verhouding betref, is die uitspraak onhoudbaar en moet dit eerder omgedraai word: Die oorwinning oor die apokaliptiek, in die vervulling van die apokaliptiese verwagting waarvolgens God nog moet handel, is die moeder van alle Christelike 


\section{Apokaliptiek en eskatologie}

teologie. Die wending waarop die apokaliptiek nog wag, het volgens die kerklike boodskap reeds gekom.

\section{APOKALIPTIEK}

Uit Schmithals se benadering is dit reeds duidelik dat apokaliptiek nie vir hom bloot die benaming van 'n literatuursoort is nie, maar 'n spesifieke wêreld-, geskiedenis- en lewenbesef. Hierdie beskouingskompleks vorm die grondslag van die apokaliptiese literatuur en dit word ook elders onder woorde gebring (Schmithals 1973:22). Die oriëntering aan die geskiedenis moet as die eerste karaktertrek van die apokaliptiek gesien word. God se plan vir die geskiedenis is gemaak en soos dit aan die apokaliptikus openbaar is, sal dit afloop (Schmithals 1973:23). Die apokaliptikus weet dat sy uur die laaste uur van die ou bedeling is; die tyd van die groot omwenteling (Schmithals 1973:25). Mense het 'n rol te speel in die grootse gebeure omdat hulle die moontlikheid het om nou die beslissing te voltrek waarin hulle eie lewe, midde in die geskiedenis, op die spel staan. Dit is gevolglik eie aan die apokaliptiek om tot boetedoening en bekering op te roep. Mense beslis self of hulle aan die nuwe wêreld gaan deelneem. Alles gebeur nou en van elke enkeling hang dit af hoe hierdie saak besleg gaan word (Schmithals 1973:29). Teen hierdie agtergrond lees Schmithals die gelykenis van die oneerlike bestuurder:

Toe roep hy die skuldenaars van sy werkgewer een vir een en vra vir die eerste: "Hoeveel skuld jy my werkgewer?" Hy antwoord: "Honderd vate olyfolie." Toe sê hy vir hom: "Vat jou skuldbewys, gaan sit en skryf gou vyftig." Daarna vra hy vir die ander een: "En jy, hoeveel skuld jy?" Hy antwoord: "Honderd sak koring." En hy sê vir hom: "Vat jou skuldbewys en skryf tagtig."

(Luk 16:5-7)

Die bestuurder gebruik die kort tyd wat vir hom oorbly. Die hoorders van die gelykenis word opgeroep om die geleentheid voor die einde van die wêreld te gebruik om vir hulle toelating tot die Godsryk te verkry. Bekering is nodig en dit is nog moontlik. Niemand sal tog met die dinge van die ewige lewe minder vernuftig wil omgaan as wat die 
oneerlike bestuurder met die dinge van die tydelike lewe omgaan nie! (Schmithals 1987:9).

Ten spyte van die groot verantwoordelikheid waarvoor die apokaliptiek die mens te staan sien kom, waag Schmithals die vermoede dat pessimisme teenoor die ervaarde en ervaarbare werklikheid die oorspronklike ervaring van die apokaliptiek is, en dat die apokaliptiek 'n poging daarstel om met hierdie ervaring positief oor die weg te kom (Schmithals 1973:32). Die apokaliptikus verloor die verantwoordelikheid teenoor die wêreld en die geskiedenis omdat die wêreld van die grond af bedorwe is. In mitologiese taal word Satan en God teenoor mekaar gestel as die beheerders van die teenswoordige en toekomstige wêrelde. Die geloof in engele en demone gee uitdrukking aan die skeiding tussen God. en hierdie wêreld. Heil kan nie in hierdie wêreldtyd verwerklik word nie. Die mens kan net daarop wag (Schmithals 1973:30-32).

Die apokaliptiek gee die radikale pessimisme oor hierdie wêreldtyd gelyk, maar kom die absolute moedeloosheid tegemoet deur vir die regverdiges die groot hoop op die komende nuwe skepping voor te hou (Schmithals 1973:33-34).

Die gevolg van die apokalitiese geloof is dat die geskiedenis totaal geprofaniseer word. Geen teologiese betekenis kan geheg word aan dit wat in die geskiedenis gebeur nie. Selfs God kan in hierdie wêreld geen heilsdaad meer verrig nie. God moet self wag dat die vasgestelde tye vervul word. Die duiwel word die god van hierdie tyd. Geen oordeel word binne die geskiedenis gevel nie, die geskiedenis self word beoordeel, die ou wêreld sal in vuur en swael vergaan, om vir die nuwe plek te maak (Schmithals 1973:61; 1979:100 vgl Heim 1955:104).

Skematies kan die apokaliptiese voorstelling so getrek word:

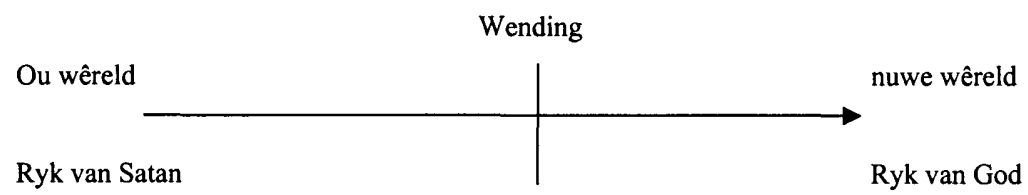




\section{ESKATOLOGIE}

Kortliks kan genoem word dat Schmithals (1973:60-61) ook die Ou Testament teenoor die apokaliptiese geloof en denke stel. Die Ou Testament verwag nie 'n verlossing van die geskiedenis nie, maar heil in die geskiedenis. God bied heil aan die volk van God as 'n moontlikheid wat in elke teenwoordige tyd bestaan. God se oordeel word voltrek in die geskiedenis en gevolglik staan sonde en geregtigheid nie weerskante van die groot wending nie, maar is dit menslike moontlikhede binne die geskiedenis. Wat die Nuwe Testament betref, kom die volgende skema na vore:

\section{Wending/Jesus Christus}

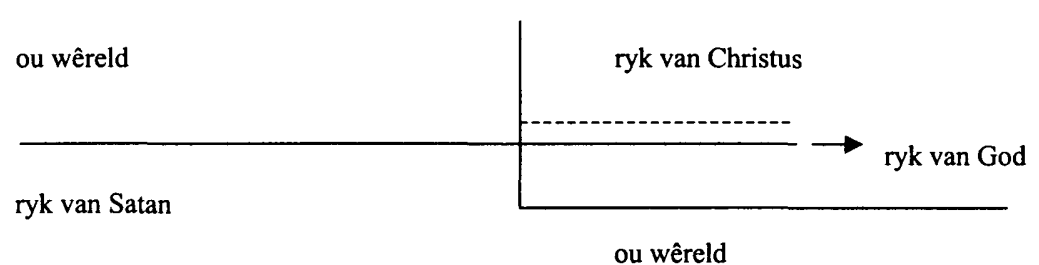

In alle variasies van die oer-Christelike teologie vind Schmithals dat die historiese gebeurtenis "Jesus Christus" as die eskatologiese gebeure verstaan word; die wending het gekom. Die Goddelike heil ontmoet mense in die Christelike verkondiging as moontlikheid in die geskiedenis en as historiese werklikheid waar hierdie moontlikheid aanvaar word. Die gemeente wat bely dat Jesus regeer, verstaan hulleself as heilsgemeente (Schmithals 1973:119).

In die formule "soos die sonde deur die dood heerskappy gevoer het, so voer ook die genade heerskappy tot die ewige lewe deur Jesus Christus, ons Here" (Rom 5:21), lees Schmithals (1988:180; vgl ook 1979:105) 'n deurbreking van die apokaliptiese denkstruktuur. Die twee-wêrelde-skema word gevolg en die aard van beide beskryf: die heerskappy van die sonde tot die dood toe en die heerskappy van die genade tot lewe. Maar in plaas van die ou en nuwe wêrelde gaan dit om die ou en nuwe mens, want die formule weet van die wending wat met Christus gekom het. Die wending word voltrek in die lewe van hulle wat midde in die wêreld van die dood die lewe ontvang. 
Schmithals (1988:65) vind dit dan ook gerade om die terme "eskatologie" en "apokaliptiek" duidelik van mekaar te onderskei. Die onderskeid maak hy in terme van die lewensbesef wat in elkeen van hierdie strukture vaardig is. Beide kry hulle onderskeie kontoere in die teenstelling met die ander. Onder "eskatologie" verstaan Schmithals die tyd- en lewensbesef, wat in die geloof aan Jesus Christus elke teenswoordige tyd as heilstyd opvat, oop na die toekoms toe. "Apokaliptiek" weer sien die teenswoordige tyd nie as heilstyd nie, maar as profane tyd (Schmithals 1973:61), al is dit die eindtyd van die ou wêreld. Die Paasgeloof bely dat die Christus-gebeure eskatologiese heilsgebeure is: "Maar nou, Christus is opgewek uit die dood, as eersteling uit die wat gesterf het" (1 Kor 15:20). Die opstanding van Christus lui die einde van die ou wêreldloop in. Die oordeel oor die ou wêreld is uitgespreek. Mense moet nie hulle lewe van die wêreld of van hulle eie moontlikhede verwag nie, want dit het geen toekoms nie. Midde in hierdie wêreld neem die Paasgeloof die heil van God waar en bely: die wêreld vergaan, die lewe het begin (Schmithals 1978:2).

Schmithals se behandeling van hierdie sake moet in verband gebring word met die belangrikheid wat die verkondiging vir hom het. Die Nuwe Testament wil die evangelie, die eskaton, dit wat God doen, ter sprake bring. Die eskatologiese heil word in die verkondiging teenwoordig gestel. Die eskatologiese woord tref mense in die geskiedenis as die einde van die geskiedenis. Dit wat God doen, doen God nie aan die geskiedenis nie, maar aan mense deur aan hulle die moontlikheid te gee om as skepsels van die Skepper te lewe.

Die Nuwe-Testamentiese voorstelling gaan tog weer akkoord met die apokaliptiese dualisme in soverre die heil nie van mense of van die geskiedenis verwag word nie, maar van God. Mense is in hulle konkrete geskiedenis die ontvangers van heil. Hulle word nie van die geskiedenis verlos nie, maar van hulle eie heilloosheid in die geskiedenis. Die apokaliptiese dualisme word 'n beslissingsdualisme. Die ou wêreld en die nuwe wêreld sluit mekaar nie uit nie, maar oorvleuel mekaar. Vir die gelowige het die einde van die ou wêreld in die tyd aangebreek en vir die ongelowige die verdoemenis midde in die tyd (Schmithals 1973:121). Schmithals (1973:120) verduidelik dat die vroeg-Christelike verkondiging gebruik mak van die dramatiese voorstellings van die apokaliptiese eindgeskiedenis om veral teen die gnostiese misverstand, as sou die heil 'n besit van die 


\section{Apokaliptiek en eskatologie}

gemeente wees, te waarsku en om die dialektiese verstaan van die heil as gawe van genade te beklemtoon. Die apokaliptiese voorstellings gee uitdrukking aan die "nog nie"karakter van die heil in verhouding tot die "reeds" daarvan. Schmithals beklemtoon steeds die dialektiese verbinding tussen die "reeds" en die "nog nie" van die heil. Die waarheid lê in die spanning en nie een van die twee spanningspole nie. Die spanning behoort nie ontspan te word nie. Die heil is klaar heeltemal teenwoordig en is tegelykertyd nog heeltemal uitstaande. Die hoëre eenheid tussen die innerlike teenstelling van "reeds" en "nog nie" is moontlik, omdat dit God se heil is wat geheel en al verwerklik waar mense hulle met hulle lewe op God se koms in Christus inlaat, maar tegelykertyd nooit die mens se besitting word nie omdat hulle dit telkens net kan verwag.

Die gelowiges verskyn wel met die laaste oordeel voor Christus: "Ons moet immers almal voor die regterstoel van Christus verskyn, sodat elkeen kan ontvang volgens wat hy tydens sy aardse lewe gedoen het, of dit nou goed was of kwaad" ( 2 Kor 5:10). Hierdie woorde bring die verantwoordelikheid na vore wat die gelowige vir die verbygaande wêreld het. Tog is die gelowiges van die oordeel van God onttrek. Saam met God oordeel hulle oor die wêreld (1 Kor 6:2). Dit is net moontlik omdat die gelowiges hierdie oordeel reeds oor hulleself voltrek het (Schmithals 1984b).

Schmithals (1980:226) beskryf Jesus se woorde aan die misdadiger aan die kruis "Ek verseker jou: Vandag sal jy saam met My in die paradys wees" (Luk 23:43) as “vertikale", Hellenistiese eskatologie. Nog 'n voorbeeld van die Hellenistiese eskatologie (Schmithals 1979:537) het Paulus aangeteken: "Ek verlang daarna om heen te gaan en met Christus te wees" (Fil 1:23). Die sin van hierdie voorstelling is dat die gemeenskap met Christus nie ophou nie, maar voortduur. Teenoor die vertikale, Hellenistiese eskatologie kan die "horisontale", apokaliptiese voorstelling van die opstanding uit die dood gestel word. In hierdie denkstruktuur is die opstanding nog uitstaande. Behalwe dat hierdie voorstelling die "eskatologiese voorbehoud", naamlik dat die nuwe lewe steeds geskenkte lewe bly, teenoor alle heilsekerheid wil handhaaf, rig dit die hoop op God die Skepper. Die opstanding uit die dood verwys die sterflike mens na die skeppingsmag van God, as hy of sy wil lewe (Schmithals 1984).

Dat die toekomsvoorstelling in die Nuwe Testament nie 'n eenheidbeeld vertoon nie, is vir Schmithals (1979:537-538; 1983:120-122) uitdrukking van die radikaliteit van 
die Christelike hoop: "Hoop wat mens sien, is geen hoop nie" (Rom 8:24). Geen toestand word beskryf nie, dit sou utopies wees. Utopieë sluit die hoop af, maak 'n einde daaraan. Terwyl ware hoop geen einde, geen resultaat ken nie. Christelike hoop is die ewige openheid vir die nuwe, onbekende wat God gee. Die gelowige hoop nie op 'n toestand nie, nie op "iets" nie, maar op lemand, op God self. Die utopiese beskrywings in die Openbaring van Johannes word omsluit deur die belydenis: "Ek is die Alfa en die Omega, die Eerste en die Laaste, die Begin en die Einde" (Op 22:13; vgl 1:17-18). Die kontinuïteit van die Christelike heil word met die voorstelling van die wederkoms van Christus uitgedruk (Schmithals 1978:163). Die komende Christus is die een wat gekom het. Niks meer kan kom as wat reeds gekom het nie. Die Een wat kom, het die dood oorwin en die lewe gebring deur die evangelie.

Waar Schmithals (1978:390-391) in 1978 nog die Pauliniese literatuur lees asof dit met apokaliptiese voorstellings, begrippe en formules deursuur sou wees, byvoorbeeld in 1 Tessalonisense 4:13-18, skryf hy hierdie gedeelte (van vers 15 af) later toe aan die byvoegingswerk van die redakteur van die hoofversameling van die Paulus-briewe (Schmithals 1984a:160-161). Hierdie verklaring verdiep en versterk die standpunt van Schmithals dat Paulus geen apokaliptikus was nie, maar dat hy 'n eskatologiese tyd- en lewensbesef in die lig van die Christus-gebeure gehad het. Die eskatologiese standpunt was van die begin af die grondslag vir sy evangelie. Daarom kan geen ontwikkeling in Paulus se toekomsvoorstellings en -verwagtinge rekonstrueer word nie. Schmithals (1988:80-81) voeg by dat Paulus in hierdie verband verteenwoordigend is vir die hele oer-Christendom in verband met die verhouding tussen eskatologie en apokaliptiek.

\section{SLOTOPMERKING}

Afgesien van die binne-dogmatiese perspektiewe wat by hierdie tema ter sprake kom, soos in die inleiding genoem is, speel dit ook nog 'n belangrike rol in die breër verband van die geestesgesteldheid van ons tyd. Die filosofiese en teologiese tradisie waarin ook Schmithals staan, kry dit reg om te teologiseer sonder om hoog op te gee oor wat God alles in die geskiedenis sou doen deur die aandag te bepaal op wat God telkens aan die mens in die geskiedenis doen. Hierdie benadering staan en val met 'n bepaalde opvatting 


\section{Apokaliptiek en eskatologie}

oor wat heil as die werksaamheid van God is, waardeur Hy die omvattende lewensmoontlikheid aan die mens bied.

Eskatologie is 'n belangrike kategorie vir die "geschichtliche" denke. Dit word eintlik 'n omskrywing vir die Goddelike werklikheid. Die andersheid van hierdie werklikheid word in persoonlike terme as die aanspraak van 'n "U" uitgedruk, waarin die mens in vryheid deur 'n ware Ander ontmoet word. Om aan hierdie aanspraak gehoor te gee is om die heerskappy van die " $U$ " te erken. Die God wat die eskatologiese aanspraak maak, is nie die God wat in terme van die bohistoriese gedefinieer word nie en God se goddelikheid lê ook nie daarin dat God ewig-onbegryplik is nie. God oefen heerskappy uit deur die mens se selfverstaan te verander. Voor God verstaan mense hulleself as begenadigde sondaars.

\section{Literatuurverwysings}

Bultmann, R 1980. Theologie des Neuen Testaments. 8.Aufl. Tübingen: Mohr. (UTB 630.)

Heim, K 1955. Die christlicehr Ethik: Tübinger Vorlesungen, nachgeschrieben und ausgearbeitet von Walter Kreuzburg. Tübingen: Katzmann.

Geyser, A 1951. Die betrekking tussen Jesus en Johannes die Doper. HTS 7(2\&3̣), 133140.

Gunning J H Jhz 1890. Onze Eeredienst: Opmerkingen over het liturgische element in den Gereformeerden cultus. Groningen: Wolters.

Schmithals, W [1970] 1972. Jesus von Nazareth in der Verkündigung der Kirche, in Jesus Christus in der Verkündigung der Kirche: Aktuelle Beiträge zum notwendigen Streit um Jesus. Neukirchen-Vluyn: Neukirchener Verlag.

- 1973. Die Apokalyptik: Einfürung und Deutung. Göttingen: Vandenhoeck. (Sammlung Vandenhoeck.)

- 1974. Geisterfahrung als Christuserfahrung, in Heitmann, C \& Mühlen, H (Hrsg), Erfahrung und Theologie des Heiligen Geistes, 101-127. Hamburg: Kösel.

- 1975. Jesus und die Apokalyptik, in Strecker, G (Hrsg), Jesus Christus in Historie und Theologie: Festschrift für Hans Conzelmann, 59-85. Tübingen: Mohr.

- 1978a. Osterfreude: 1 Kor 15, 20. Berliner Sonntagsblatt 13, 2. 
Schmithals, W 1978b. Zur Herkunft der gnostische Elemente in der Sprache des Paulus, in Aland, B (Hrsg), Gnosis, 385-414. Göttingen: Vandenhoeck.

- 1979. Das Evangelium nach Markus, 2 Bde. Gütersloh: Mohn. (ÖTK 2/1; 2/2; GTBSiebenstern 502; 503.)

- 1980. Das Evangelium nach Lukas. Zürich: Theologischer Verlag. (ZBK NT 3.1.)

- 1984a. Die Briefe des Paulus in ihrer ursprüngliche Form. Zürich: Theologischer Verlag. (Zürcher Werkkommentare zur Bibel.)

- 1984b. Gedanken zum Pfingstfest. Der Tagesspiegel 10. Juni 1984.

- 1985. Einleitung in die drei ersten Evangelien. Berlin: De Gruyter. (De Gruyter Lehrbuch.)

- 1988a. Der Römerbrief: Ein Kommentar. Gütersloh: Mohn.

- 1988b. Eschatologie und Apokalyptik. VuF 33(1), 64-82.

- 1994. Theologiegeschichte des Urchristentums: Eine problemgeschichtliche Darstellung. Stuttgart: Kohlhammer. 